Medieval Studies, vol. 22, 2018 / Studia z Dziejów Średniowiecza, tom 22, 2018

Ewa Bojaruniec-Król

(Museum of Gdańsk)

https://orcid.org/0000-0001-5846-747X

\title{
The ennoblement of Gdańsk patricians in the second half of the fifteenth century and the early sixteenth century
}

Keywords: The ennonblement, Gdańsk, Kazimierz Jagiellończyk, coats of arms, Hansa

The Thirteen Years' War of 1454-1466, fought between Poland and the Teutonic Order, resulted in Pomerelia and Gdańsk becoming part of the Kingdom of Poland. ${ }^{1}$ In recognition of Gdańsk's contribution to the war effort against the Teutonic Order, the King of Poland, Kazimierz Jagiellończyk (Casimir IV Jagiellon), awarded the city four privileges. ${ }^{2}$ Issued in the period between 1454 and 1457,

1 K. Górski, Pomorze $w$ dobie wojny trzynastoletniej [Pomerania at the time of the Thirteen Years' War], Poznań 1932, pp. 117-256; M. Biskup, 'Walka o zjednoczenie Pomorza Wschodniego z Polska w połowie XV wieku' [The struggle for Pomerelia's unification with Poland in the latter half of the fifteenth century], in: Szkice z dziejów Pomorza, vol. 1, Pomorze średniowieczne, ed. G. Labuda, Warszawa 1958, pp. 354-368; idem, Zjednoczenie Pomorza Wschodniego z Polskq w połowie XV wieku [The unification of Pomerelia with Poland in the fifteenth century], Warszawa 1959, pp. 278-331; idem, Trzynastoletnia wojna z zakonem krzyżackim 1454-1466 [The Thirteen Years' War with the Teutonic Order, 1454-1466], Warszawa 1967, passim; H. Samsonowicz, 'Gdańsk w okresie wojny trzynastoletniej' [Gdańsk during the Thirteen Years' War], in: Historia Gdańska (hereinafter: HG), vol. 2, ed. E. Cieślak, Gdańsk 1982, pp. 43-76.

2 Archiwum Państwowe w Gdańsku [State Archive in Gdańsk] (hereinafter: APG), 300, D/1, 7; 300, D/1, 27; 300, D/1, 38; 300, D/1, 44; Acten der Ständetage Preussens unter der Herrschaft des Deutschen Ordens, Bd. 4, ed. M. Toeppen, Leipzig 1884, nos. 282, 314, 367, 369; P. Simson, Geschichte der Stadt Danzig, Bd. 4, Urkunden bis 1626, Danzig 1918, nos. 137, 138, 141, 142; M. Biskup, Stosunek Gdańska do Kazimierza Jagiellończyka w okresie wojny trzynastoletniej 1454-1466 [Gdańsk's attitude towards Casimir IV Jagiellon during the Thirteen Years' War, 1454-1466], Torun 1952 (Roczniki Towarzystwa Naukowego w Toruniu, vol. 56, no. 1) pp. 60-65; Katalog dokumentów 
the documents granting these rights formed the keystone of Gdańsk's exceptional political and economic status, not only in Royal Prussia, but also within the Kingdom of Poland. ${ }^{3}$ It was at that time that Gdańsk gained significant autonomy in administrative, judicial, and financial matters as well as in determining foreign (maritime) policy. ${ }^{4}$

During the late medieval period, the wealth of the city located at the mouth of the Vistula River was built on long-distance overseas trade and cooperation with other member-cities of the Hansa, in particular with Lübeck. ${ }^{5}$ The lands around the Baltic Sea offered ample opportunities for migrants from all quarters of the Hanseatic world ${ }^{6}$

i listów królów polskich z Archiwum Państwowego w Gdańsku (do 1492 roku) [Catalogue of documents and letters of the kings of Poland. From the State Archive in Gdańsk (up to 1492)], eds. M. Grulkowski, B. Możejko, S. Szybkowski, Gdańsk 2014, nos. 20, 37, 47, 49; M. Grulkowski, 'Przywileje Kazimierza IV Jagiellończyka z lat 1454-1457' [Privileges awarded by Casimir IV Jagiellon during 1454-1457], in: Pod królewska korona. Kazimierz Jagiellończyk a Gdańsk w 560. rocznicę wielkiego przywileju. Katalog wystawy zorganizowanej przez Muzeum Historyczne Miasta Gdańska w dniach 26 maja-1 października 2017 roku [Catalogue of the exhibition held at the Gdańsk History Museum (Muzeum Historyczne Miasta Gdańska) from 26 May to 1 October 2017], ed. E. Bojaruniec-Król, Gdańsk 2017, pp. 9-11, 25-28; B. Możejko, 'The political history of Gdańsk: from the early fifteenth to the sixteenth century,' in: New Studies in Medieval and Renaissance Poland and Prussia. The Impact of Gdańsk, ed. eadem, London-New York 2017, pp. 35-37; M. Grulkowski, Privilegia Casimiriana. Przywileje króla Kazimierza IV Jagiellończyka dla Gdańska w okresie wojny trzynastoletniej [Privilegia Casimiriana. The privileges awarded to Gdańsk by Casimir IV Jagiellon during the Thirteen Years' War], [typescript provided by the author].

${ }_{3}$ M. Grulkowski, Przywileje Kazimierza IV Jagiellończyka..., p. 11.

4 E. Cieślak, 'Przywileje Gdańska z okresu wojny 13-letniej na tle przywilejów niektórych miast bałtyckich' [Privileges awarded to Gdańsk during the Thirteen Years' War in comparison with privileges enjoyed by other Baltic cities], Czasopismo Prawno-Historyczne, 6, 1954, pp. 61-119; B. Możejko, 'Przywileje Kazimierza Jagiellończyka z 1457 r. dla Gdańska a zmiany heraldycznego wizerunku miasta' [The privileges awarded to Gdańsk in 1457 by Casimir IV Jagiellon and the changes to the city's heraldic image], in: Okręt Kościoła z gdańskiego Dworu Artusa. Materiały z sesji zorganizowanej przez Muzeum Historyczne Miasta Gdańska dnia 25 maja 2007 roku w 550. rocznicę nadania Miastu honorowego przywileju przez króla Kazimierza Jagiellończyka [Proceedings of a seminar held by the Gdańsk History Museum on 25 May 2007 on the $550^{\text {th }}$ anniversary of King Casimir IV Jagiellon granting the city an honorary privilege], Gdańsk 2008, (Res Gedanenses. Studia i Materiały Muzeum Historycznego Miasta Gdańska, vol. 1), p. 16.

5 M. Biskup, 'Rola Gdańska w Związku Miast Hanzeatyckich' [Gdańsk's role in the Hanseatic League], in: HG, vol. 1 (do roku 1454), ed. E. Cieślak, Gdańsk 1978, pp. 428-431.

6 M. Biskup, 'Migracje ludnościowe' [Population migrations], in: HG, vol. 1, pp. 383-384; J. Zdrenka, Główne, Stare i Młode Miasto Gdańsk i ich patrycjat w latach 1342-1525 [Gdańsk's Main, Old, and Young Towns and their patriciate], Gdańsk 1992, 
to build swift and successful careers. At this point, it should be noted that burghers who came to Gdańsk from areas of the German cultural realm, such as the Rhineland or Lübeck, had their own coats of arms in the form of hereditary emblems that their families had used for centuries. Images of these heraldic devices were widely represented in Gdańsk's art and architecture. An example from St Mary's Church is provided by an epitaph painting commemorating the von der Beke family, who came to the city from Cologne in the Rhineland. Dating from 1425-1430, the painting features the family's coat of arms in the lower left corner. ${ }^{7}$

In the latter half of the fifteenth century, Gdańsk's economic relations with Poland and the Grand Duchy of Lithuania resulted in the city becoming the principal port handling almost all of the foreign trade transacted by the extensive Polish state. ${ }^{8}$ Gdańsk's burghers increasingly fostered commercial contacts with Polish and Lithuanian nobles. Through family connections and their own diligence, they also managed to achieve high social standing and considerable wealth, forming an elite who shaped the city's political, economic, and social

pp. 84-86; H. Samsonowicz, 'Geografia powiązań rodzinnych patrycjatu gdańskiego w średniowieczu' [The geography of family connections among Gdańsk's patriciate in the Middle Ages], in: Veberabiles, nobiles et honesti. Studia z dziejów spoteczeństwa Polski średniowiecznej, eds. A. Radzimiński, A. Supruniuk and J. Wroniszewski, Toruń 1997, p. 319; E. Bojaruniec-Król, 'Nobilitacje patrycjuszy gdańskich wyrazem budowania niezależności politycznej i ekonomicznej elit zasiadających we władzach miejskich w XV-XVI w.' [The ennoblement of Gdańsk patricians as an expression of the growing political and economic independence of the city council elite during the fifteenth and sixteenth centuries], in: Rzadzacy i rzadzeni. Wtadza i społeczeństwo Gdańska od średniowiecza po wspótczesność. Materiały z konferencji naukowej zorganizowanej przez Muzeum Historyczne Miasta Gdańska i Stowarzyszenie Rajcy Gdańscy w dniach 24 października 2014 r., 29-30 maja 2015 r. [Proceedings of a conference organized by the Gdańsk History Museum and the Gdańsk Councillors Association and held on 24 October 2014 and 29-30 May 2015], eds. S. Bykowska, E. Kizik, P. Paluchowski, Gdańsk 2015, pp. 22-23.

7 See E. Bojaruniec, 'Geneza herbu gdańskiej rodziny patrycjuszowskiej von der Beków' [The origins of the Gdańsk patrician family von der Beke's coat of arms], in: Komturzy, rajcy, żupani. Studia z dziejów średniowiecza, vol. 11, ed. B. Śliwiński, Malbork 2004, pp. 45-59; P. Oliński, Fundacje mieszczańskie w miastach pruskich w okresie średniowiecza i na progu czasów nowożytnych (Chetmno, Toruń, Elblag, Gdańsk, Królewiec, Braniewo) [Burgher endowments in Prussian towns during the Middle Ages and at the dawn of the early modern period], Torun 2008, pp. 277-280.

8 M. Biskup, Zjednoczenie Pomorza..., pp. 47-105; J. Zdrenka, Gtówne..., p. 86; H. Samsonowicz, 'Miejsce Gdańska w gospodarce europejskiej w XV wieku' [Gdańsk's position in the European economy during the fifteenth century], in: HG, vol. 2, p. 91; idem, 'Geografia powiązań...,' p. 320. 
landscape. The fluctuating political circumstances of the day allowed Gdańsk's patricians to petition subsequent kings of Poland for patents of nobility. In order to enhance their position and prestige, many affluent burghers, such as the von der Bekes, the Zimmermans, the Ferbers, and the Werdens, endeavoured to obtain royal ennoblement by having their own coats of arms approved, or by being granted the right to use the coats of arms of renowned and respected Polish noble families, among them the Łaski family (Korab coat of arms), the Lubrański's (Godziemba coat of arms), and the Szydłowiecki's (Odrowąz coat of arms). ${ }^{9}$ Thanks to the generosity of the Polish kings, the heraldic badges used by the patriciate were elevated to the rank of family coats of arms, usually being endorsed without any changes to their existing designs, which were already widely known throughout the city, as was the case with those of the Ferber and Giese families. ${ }^{10}$

The first recorded recipient of a royal patent of nobility was the town councillor Joachim von der Beke (1410-1463), ${ }^{11}$ who was ennobled by Kazimierz IV Jagiellończyk on 27 May 1457 through gaining approval for his existing coat of arms (Fig. 1). ${ }^{12}$ The relevant document was

$9 \quad$ E. Bojaruniec, Herby mieszczan gdańskich od XV do XVIII wieku [Coats of Arms of Gdańsk burghers from the fifteenth to the eighteenth Century], Gdańsk 2014, (Materiały Towarzystwa 'Dom Uphagena' 1), p. 17; eadem, 'Social Advancement among Gdańsk Patrician families in Gdańsk in the late Middle Ages and the Early Modern Period as exemplified by the Ferber Family,' Acta Historica Universitatis Klaipedensis, 29 [Mobility in the Eastern Baltics], 2014, pp. 155-156.

10 E. Bojaruniec-Król, 'Nobilitacje patrycjuszy...,' p. 25.

11 J. Zdrenka, Urzędnicy miejscy Gdańska w latach 1342-1792 i 1807-1814 [The city officials of Gdańsk, 1342-1792 and 1807-1814], vol. 2, Biogramy, Gdańsk 2008, p. 27, no. 57 (Fontes Commentationesque ad Res Gestas Gedani et Pomeraniae).

12 APG, 300, D/82, no. 55; Polska Akademia Nauk Biblioteka Gdańska [Gdańsk Library of the Polish Academy of Sciences] (hereinafter: PAN Biblioteka Gdańska), 616, k. 8-8v; Z. Wdowiszewski, 'Wiadomości o gdańskim kopiariuszu urzędowym z XVII w. i o zawartych w nim nobilitacjach i indygenatach' [Information on Gdańsk's seventeenth-century official cartulary and the grants of nobility and naturalisation recorded therein], $\mathrm{MH}, 15,1936$, pp. 29, 33; idem, 'Regesty nobilitacji w Polsce (1404-1794)' [Registers of grants of ennoblement in Poland, 1404-1794], in: Materiaty do biografii, genealogii i heraldyki polskiej. Źródta i opracowania, vol. 9, Buenos Aires-Stockholm 1987, pp. 2-3; J. Michta, 'Nobilitacja Joachima de Beke wystawiona w Gdańsku, 27 maja 1457 roku' [The grant of nobility issued to Joachim de Beke in Gdańsk, 27 May 1457], in: Nobilitacje i indygenaty w Rzeczypospolitej 1434-1794, fasc. 1, Kielce 1991, n. pag.; B. Trelińska, 'Nobilitacja Joachima de Beke' [The ennoblement of Joachim de Beke], in: Veberabiles, nobiles et honesti. Studia z dziejów społeczeństwa Polski średniowiecznej, eds. A. Radzimiński, A. Supruniuk, J. Wroniszewski, Toruń 1997, pp. 301-304; Album armorum Nobilium Regni Poloniae XV-XVIII saec. Herby nobilitacji $i$ indygenatów XV-XVIII $w$. [Armorial bearings of the nobility 


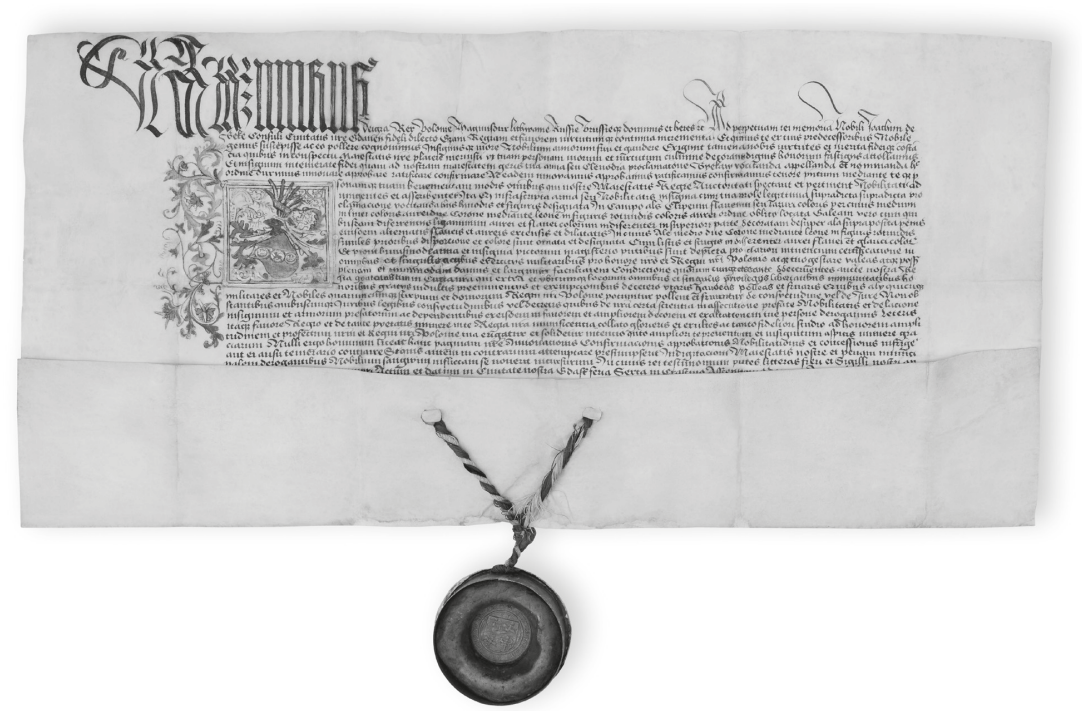

Fig. 1. Patent of nobility of Joachim von der Beke issued by the chancery of King Kazimierz IV Jagiellończyk, 1457. From the collections of the State Archive in Gdańsk, 300, D/82, no. 55

issued in Gdańsk during the king's sojourn there, two days after the city had been ceremonially granted the privilege of a coat of arms. ${ }^{13}$ The burgher's ennoblement came about as a result of the substantial financial contributions that the von der Beke family had made to the king's cause during the Thirteen Years' War. ${ }^{14}$ The patent not only conferred nobility on its recipient and approved his family coat of arms (consisting of a blue shield with a gold bend emblazoned with two gold crowns in circles flanking a lion passant, also in a gold circle), ${ }^{15}$

and naturalized Polish nobles, fifteenth-eighteenth centuries], ed. B. Trelińska, Lublin 2001, pp. 47-48, no. 13; E. Bojaruniec, 'Geneza herbu...,' pp. 45-49; E. Bojaruniec-Król, 'Nobilitacje patrycjuszy...,' pp. 25-27.

13 B. Śliwiński, 'Początki herbu Gdańska' [The origins of Gdańsk's coat of arms], in: Pod królewska koronq..., pp. 18-19.

14 E. Cieślak, Walki ustrojowe $w$ Gdańsku i Toruniu oraz w niektórych miastach hanzeatyckich $w X V w$. [Political struggles in Gdańsk, Toruń and other Hanseatic towns in the fifteenth century], Gdańsk 1960, p. 91, note 58.

15 J. Szymański, Herbarz rycerstwa polskiego z XVI wieku [An armorial of Poland's sixteenth century knights], Warszawa 2001, p. 20; E. Bojaruniec, 'Geneza herbu..., p. 55. 
but it also entitled him to a landed estate-the village of Stężyca on Lake Raduńskie. ${ }^{16}$ Possession of land was a condition of nobility in the Crown, which placed the Gdańsk nobility in a unique position in relation to other ennobled citizens.

Ennoblement was an important event in the life of Gdańsk's burgher patricians, as it affected not only their own civic standing, but also that of their offspring. Furthermore, it laid the foundations for the emergence of an elite of municipal officials who shaped the political life of Gdańsk and represented the city at Hanseatic assemblies. One of the most celebrated of Gdańsk's ennobled families was the Ferber clan, whose descendants belonged to the city's social elite from the mid-fifteenth to the end of the eighteenth centuries. Numerous members of this family held some of the most important civic posts in Gdańsk. ${ }^{17}$ They were keen to make use of every opportunity to emphasise their social standing, adding their coat of arms to each of the furnishings they donated to their family chapel in St Mary's Church in Gdańsk, such as the Small Ferber Altarpiece (1484-1490) and the epitaph painting of Nale Ferber-Langenbeke (c.1500). Representations of their heraldic signs also featured on portraits of individual family members and items such as chairs and door locks. ${ }^{18}$ They could also be found in many locations around the city, for example above the entrance to the rectory of St Mary's Church. The Ferbers made a name for themselves among Gdańsk's patriciate by taking measures to have their noble ancestry recognised both by the Polish king and by the imperial court. In 1515, during a meeting of three monarchs-King Zygmunt I Stary (Sigismund I 'the Old') of Poland, his brother King Vladislaus II of Bohemia and Hungary, and the Holy Roman Emperor Maximilian I-held in Pressburg

16 M. Biskup, Stosunek Gdańska..., p. 124; E. Bojaruniec, 'Geneza herbu...,' p. 57; eadem, 'Beke Joachim,' in: Encyklopedia gdańska, ed. B. Śliwiński, Gdańsk 2012, p. 75; E. Bojaruniec-Król, 'Nobilitacje patrycjuszy...,' p. 26.

17 See J. Zdrenka, Urzędnicy..., pp. 85-95, nos. 254-268; E. Bojaruniec-Król, 'Nobilitacje patrycjuszy...,' p. 33-36; eadem, 'Social Advancement...,' pp. 157-158. For biographies of Gdańsk mayors from the Ferber family, see Poczet soltysów, burmistrzów, nadburmistrzów, przewodniczacych Miejskiej Rady Narodowej i prezydentów Gdańska od XIII do XXI wieku, ed. B. Możejko, Gdańsk 2015, pp. 106-108, 119-123, 148-153,191-193, 219-221, 225, 252-253.

18 A chair and door lock bearing the Ferber family coat of arms are held in the collections of the National Museum in Gdańsk under inventory numbers MNG/SD/302/ $\mathrm{Mb}$ and $\mathrm{MNG} / \mathrm{SD} / 486 / \mathrm{Mt}$, respectively. 
(Bratislava) and Vienna, ${ }^{19}$ nobility was conferred on the mayor of Gdańsk Eberhard Ferber (1463-1529), ${ }^{20}$ his wife and their children (Fig. 2). ${ }^{21}$ Zygmunt I Stary awarded the patrician noble status, endorsed his family's coat of arms - a gold shield emblazoned with three black boars' heads - and granted him, in perpetuity, the Crown estate of Tczew (Dirchau) and other landed properties. ${ }^{22}$

Here we have a very interesting example of a single patent combining two methods of gaining admission to the rank of nobility; Eberhard Ferber and his children were granted their own heraldic badge, while

19 K. Baczkowski, Zjazd wiedeński 1515. Geneza, przebieg $i$ znaczenie [The First Congress of Vienna 1515. Its origins, course and significance], Warszawa 1975, pp. 173-233.

20 E. Kestner, 'Eberhard Ferber Burgermeister von Danzig,' Zeitschrift des Westpreussischen Geschichtsvereins, 2, 1880, pp. 19-95; ibidem, 3, 1880, pp. 1-50; F. Schwarz, 'Eberhard Ferber,' in: Altpreussische Biographie, Bd. 1, Abegg-Malten, ed. C. Krollman, Königsberg 1936, p. 179; S. Bodniak, 'Ferber Eberhard,' in: Polski słownik biograficzny, vol. 6, Dunin Rodryg-Firlej Henryk, ed. W. Konopczyński, Kraków 1948, pp. 415-417; H. Zins, Ród Ferberów i jego rola $w$ dziejach Gdańska w XV i XVI wieku [The Ferber clan and their role in the history of Gdańsk in the fifteenth and sixteenth centuries], Lublin 1951, pp. 29-96; M. Bogucka, 'Eberhard Ferber (1463-1529), burmistrz gdański, dyplomata' [Eberhard Ferber (1463-1529), mayor of Gdańsk and diplomat], Pomorze Gdańskie, 10, 1977, pp. 27-33; eadem, Człowiek przełomu epok: Eberhard Ferber 1463-1529 [Eberhard Ferber 1463-1529: a man on the cusp of two eras], in: Homines et societas. Czasy Piastów i Jagiellonów, ed. J.M. Piskorski, Poznań 1997, pp. 205-212; W. Szczuczko, 'Eberhard Ferber,' in: Stownik biograficzny Pomorza Nadwiślańskiego, vol. 1, ed. S. Gierszewski, Gdańsk 1992, pp. 410-411; J. Zdrenka, Urzędnicy..., vol. 2, pp. 85-86, no. 254; E. Bojaruniec, 'Ferber Eberhard,' in: Encyklopedia gdańska..., pp. 277-278; eadem, 'Social Advancement...,' pp. 155-156; eadem, 'Eberhard Ferber,' in: Poczet sołtysów, burmistrzów..., pp. 119-123.

21 APG, 300, D/82, no. 230 b; Matricularum Regni Poloniae summaria, excussis codocibus, qui in Chartophylacio Maximo Varsoviensi asservantur, vol. 4, Sigismundi I regis tempora complectens (1507-1548), vol. 1, Acta cancellariorum 1507-1548, p. 144, no. 2486; Z. Wdowiszewski, 'Regesty nobilitacji...,' pp. 8-9, J. Michta, 'Nobilitacja Eberharda Ferbera i jego dzieci Jana, Tiedemanna, Jerzego, Barbary oraz żony Gertrudy Ferber wystawiona w Posoniu (Pressburgu-Bratislava)' [The letters of ennoblement of Eberhard Ferber and his children Johann, Tiedemann, Georg, Barbara, and his wife Gertrude Ferber issued in Pressburg-Bratislava], in: Nobilitacje i indygenaty, fasc. 7, Kielce 1993, passim; Album armorum..., p. 71, no. 85; Materiaty genealogiczne, nobilitacje, indygenaty $w$ zbiorach Archiwum Głównego Akt Dawnych $w$ Warszawie [Genealogical, ennoblement and naturalisation records held in the Central Archives of Historical Records in Warsaw], ed. A. Wajs, Warszawa 2001, p. 40.

22 M. Bogucka, Człowiek przełomu..., p. 209; E. Bojaruniec, 'Ferber Eberhard,' in: Encyklopedia gdańska..., p. 277; eadem, 'Eberhard Ferber,' in: Poczet sołtysów, burmistrzów..., p. 123. 


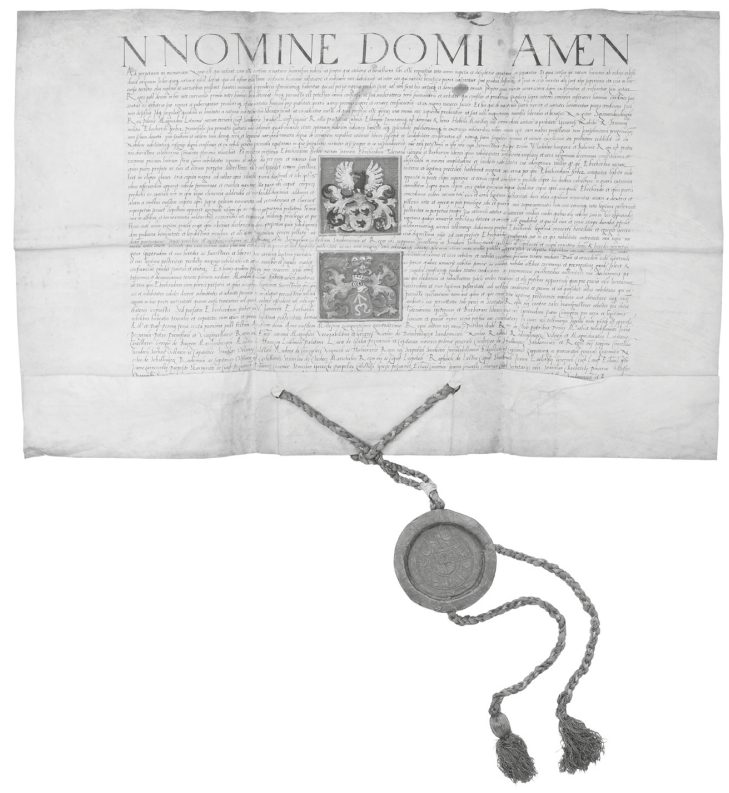

Fig. 2. Patent of nobility of Gdańsk Mayor Eberhard Ferber, his children and wife Gertrude issued by the chancery of King Zygmunt I Stary, 1515. From the collections of the State Archive in Gdańsk, 300, D/82, no. 230 b

his wife Gertrude, née Ruden (d. 1523), ${ }^{23}$ was granted the right to use the Polish Odrowazz coat of arms, which was used, among others, by the wealthy and influential Szydłowiecki family. ${ }^{24}$ In consequence, children born of the marriage of Eberhard and Gertrude were able to prove both their paternal and maternal nobility. ${ }^{25}$ The respective coats of arms of this husband and wife can be seen in a copperplate

23 D. Weichbrodt-Tiedemann, Patrizier, Bürger, Einwohner der Freien und Hansestadt Danzig in Stamm - und Nementafeln vom 14.-18. Jahrhundert, vol. 4, Klausdorf 1988, p. 168.

${ }_{24}$ E. Bojaruniec, 'Social Advancement...,' pp. 155-156; eadem, Herby mieszczan..., p. 15 .

25 J. Szymański, 'Indygenat czy nobilitacja' [Naturalisation or ennoblement], Acta Universitatis Nicolai Copernici', Nauki Humanistyczno-Społeczne, vol. 26, Historia, 1992, fasc. 240, p. 192; H. Seroka, 'Heraldyka nobilitacji Zygmunta Starego' [The heraldry of those ennobled by Sigismund I the Old], Rocznik Polskiego Towarzystwa Heraldycznego, New Series, vol. 2 (XIII), 1995, p. 75; Album armorum..., p. 6. 
portrait of their youngest son, Konstantin Ferber I (1520-1588), ${ }^{26}$ mayor of Gdańsk, produced in 1586 by the renowned engraver Nicolaus Andrea. ${ }^{27}$ The ennoblement of patrician men and women was meant to guarantee that their children would have noble ancestry through both parents. In keeping with the provisions of the 1505 Diet of Radom, nobility derived from being born of a father and mother who came from the same social class. ${ }^{28}$ An example from Gdańsk of a patrician couple who each had noble status conferred on them independently is provided by Matthias and Dorothea Zimmermann. Dorothea (1459-1511), ${ }^{29}$ née Ferber, was granted the right to use the Godziemba coat of arms ${ }^{30}$ (Fig. 3) by letters patent issued in 1505 by the chancery of King Aleksander Jagiellończyk (Alexander I Jagiellon), while her husband, Gdańsk mayor Matthias Zimmermann (1445-1513), ${ }^{31}$ was ennobled and granted the right to use the Korab coat of $\operatorname{arms}^{32}$ (Fig. 4). Another

${ }^{26} \quad$ F. Schwarz, 'Ferber Konstantin,' in: AB, vol. 1, pp. 180-181; S. Bodniak, 'Ferber Konstanty (starszy)' [Konstantin Ferber (the Elder)], in: PSB, vol. 6, pp. 417-418; H. Zins, Ród Ferberów..., pp. 96-109; W. Szczuczko, 'Ferber Konstanty starszy' [Konstantin Ferber the Elder], in: SBPN, vol. 1, pp. 413-414; D. Kaczor, 'Ferber Constantin,' in: Encyklopedia gdańska..., pp. 276-277; S. Kościelak, 'Constantin Ferber,' in: Poczet sołtysów, burmistrzów..., pp. 148-152.

27 See PAN Biblioteka Gdańska, inv. no. 4832. A portrait of Konstantin Ferber I featuring the Ferbers' own armorial bearings and the Odrowąż coat of arms can be found among the manuscripts held in the collections of the State Archive in Gdańsk, see APG, 300, R/Ll 25, p. 47.

28 J. Szymański, Indygenat czy nobilitacja..., p. 192.

${ }_{29}$ H. Zins, Ród Ferberów..., pp. 12-13; D. Weichbrodt-Tiedemann, Patrizier..., vol. 1, p. 168, 500; ibidem, vol. 5, p. 295.

30 Archiwum Główne Akt Dawnych w Warszawie [Central Archives of Historical Records in Warsaw] [hereinafter: AGAD], Metryka Koronna [The Crown Register] [hereinafter: MK] 21, k. 196; PAN Biblioteka Gdańska, Ms 616, k. 19-20; APKr, Oddział I, 1571/F.79, k. 35; Biblioteka Czartoryskich w Krakowie [The Czartoryski Library in Krakow], rkps 964, k. 61; MRPS, vol. 3 (Alexandri regis tempora complectens (1501-1506)), p. 140, no. 2133; Z. Wdowiszewski, 'Wiadomości...,' p. 29, 34; idem, 'Regesty nobilitacji..., p. 5; Album armorum..., p. 58, no. 45; Materiaty genealogiczne..., p. 33; E. Bojaruniec, Herby mieszczan ..., pp. 15-16.

31 J. Zdrenka, 'Zimmermann Maciej h. Korab' [Matthias Zimmermann of the Korab coat of arms], in: SBPN, Suplement 1, ed. Z. Nowak, pp. 362-3-63; idem, Urzędnicy..., vol. 2, p. 388, no. 1313; idem, 'Zimmermann Matthias,' in: Encyklopedia gdańska..., p. 1140; idem, 'Matthias Zimmermann,' in: Poczet sottysów, burmistrzów..., pp. 116-119; E. Bojaruniec-Król, 'Nobilitacje patrycjuszy...,' pp. 30-31.

32 AGAD, MK 21, k. 24-25; APG, 300, R/Uu, no. 18; PAN Biblioteka Gdańska, Ms 616, k. 20-22; Biblioteka Czartoryskich w Krakowie, rkps. 964, k. 61; MRPS, vol. 3, pp. 95-96, no. 1527; Z. Wdowiszewski, 'Wiadomości...,' pp. 29, 33-34; idem, 'Regesty nobilitacji...,' p. 4; Album armorum..., p. 56, no. 38; Materiaty genealogiczne..., p. 33; E. Bojaruniec-Król, Nobilitacje patrycjuszy..., pp. 30-31; eadem, 'Ceremony and pleasure 
example is that of Ursula von Campen, who was granted the right to use the Ogończyk coat of arms by a patent issued in $1526^{33}$ and was married in that same year to the Polish nobleman Jan Sokołowski (d. 1546), holder of the Pomian coat of arms. ${ }^{34}$

Returning to the ennoblement of Eberhard Ferber, it is worth noting that he did not stop at just one royal patent. He secured a second title for himself and his descendants from Maximilian I Habsburg on 29 July 1515, during the Congress of Vienna (Fig. 5). To emphasize its prestige, the Ferber family coat of arms was subsequently embellished by the addition of peacock feathers and a gold crown. ${ }^{35}$ The fact that Ferber received an imperial patent points to a certain independence, and to the diplomatic skills of this burgher, especially given Gdańsk's complicated situation arising from disputes over the city's jurisdiction between Zygmunt I and Maximilian I. ${ }^{36}$ By maintaining a neutral stance throughout this time, Ferber was able to gain grants of nobility both from the Polish king and from the emperor of the Habsburg dynasty. The fact that the imperial patent makes no mention of the mayor's wife, Gertrude, is understandable, as the emperor's authority had no influence on ennoblement through heraldic adoption under the Polish Odrowąz coat of arms. ${ }^{37}$

Apart from being inducted into the nobility by gaining approval for their own coats of arms, Gdańsk's patricians could also achieve noble

on the occasion of the visit to Gdańsk in 1504 of Aleksander Jagiellończyk, King of Poland, and his wife Helena,' in: New Studies in Medieval..., p. 195.

33 AGAD, MK 38, k. 709-710; MRPS, vol. 4, pt. 1, p. 289, no. 4915; Z. Wdowiszewski, 'Regesty nobilitacji...', p. 11; Album armorum..., p. 83, no. 116; Materiaty genealogiczne..., p. 27; E. Bojaruniec, Herby mieszczan..., p. 16.

${ }_{34}$ Urzędnicy Prus Królewskich XV-XVIII wieku. Spisy [Lists of Royal Prussian officials of the fifteenth-eighteenth centuries], ed. K. Mikulski, Wrocław-WarszawaKraków 1990, pp. 54, 86, 135; W. Szczuczko, 'Sokołowski Jan herbu Pomian (zm. 1546)' [Jan Sokołowski of the Pomian coat of arms (d. 1546)], in: SBPN, vol. 4, pp. 238-239; S. Szybkowski, 'W Czechach podskarbi, w Polsce kasztelan. U źródeł nowożytnej kariery Sokołowskich herbu Pomian' [Grand treasurer in Bohemia, castellan in Poland. The foundations underpinning the rise of the Sokolowski family (of the Pomian coat of arms) in the early modern period], in: Rola komunikacji i przestrzeni w średniowiecznych $i$ nowożytnych dziejach Czech $i$ Polski, eds. A. Paner and W. Iwańczak, Gdańsk 2008, p. 230.

35 APG, 300, D/82, no. 230 a; E. Bojaruniec, Herby mieszczan..., p. 16; E. Bojaruniec-Król, ‘Nobilitacje patrycjuszy...,' pp. 36-37.

36 H. Samsonowicz, 'Rola Gdańska w życiu stanowym Prus Królewskich i w życiu politycznym Rzeczypospolitej' [Gdańsk's role in the administrative life of Royal Prussia and the political life of the Polish-Lithuanian Commonwealth], in: HG, vol. 2, p. 278.

37 E. Bojaruniec, Herby mieszczan..., pp. 16-17. 
24 .

Q Guversis ac singulis, crijuscung's Status, gradus, conditionis seu dignita tis extiterint, pontium noticiam halitans Inis nris gratiosissionis, gratiosis, majonilus colendis et amicis hononandis, obseguionum el stadiorum nrórofficia

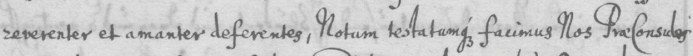
et Consules Regie (wilatis Gedanen, exhibitas notis esse lras Originales eL

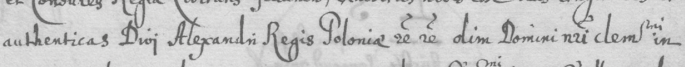

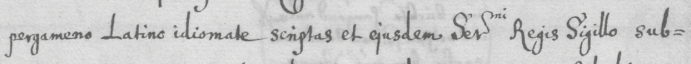
appenso munitas, petitumg'́ a nobis ut earandem consonum eh fidedignum exemplum sub sigillo civitatis nre in forma Vidimus guod vorant, ederemus, qlos itag a guictate postulatoram perpensa, predictas hiris in manus simp. simus, vidimus, legimus, ct undiguagis taim in scingtura guam sigillo saras, integras, omnigy, prorsus suspicione carentes reperimus. Troinde casdem tona fide in hane formam transcribi demandavionus, estg' earandem Lrar tenor falis ut siguitur.

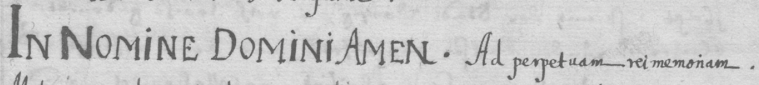

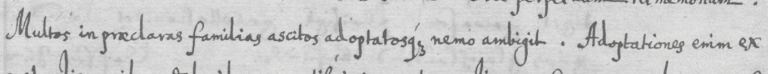

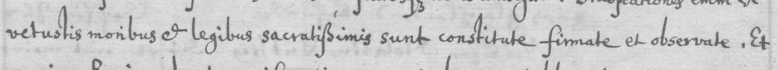

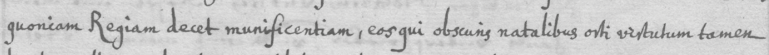

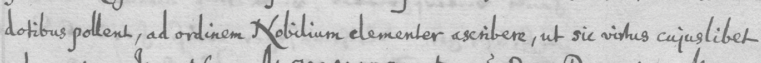

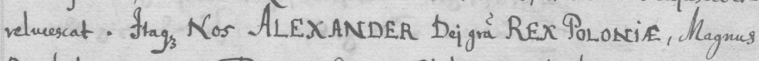

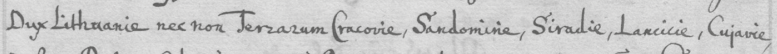

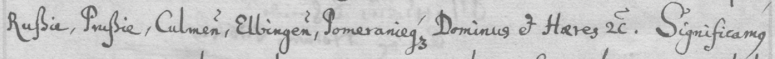

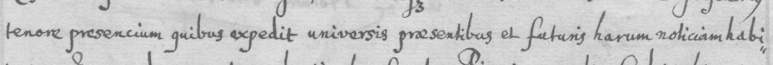

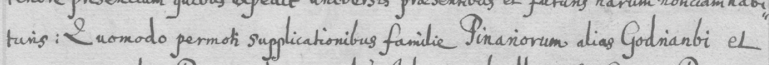

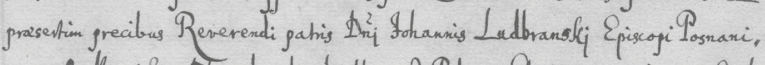

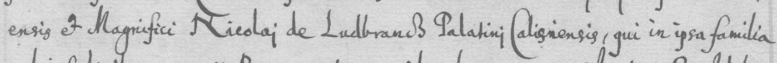

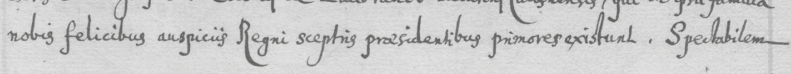

Fig. 3. Copy of Dorothea Zimmermann's patent of nobility issued by the chancery of King Aleksander Jagiellończyk, 1659. From the collections of the Gdańsk Library, Polish Academy of Sciences, Ms 616, pp. 24-26 
Dorotheam Nobilis ef Famosi Mathie Eimerman Irofonsulis el Burggrabii

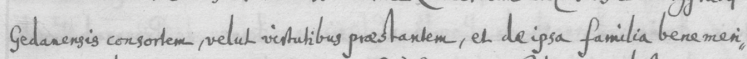

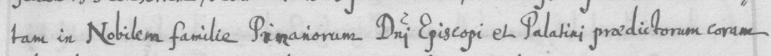
robig adoplatam-, Norigsi Nebilem creang fosamǵ, adoptionem et asscriptionem-

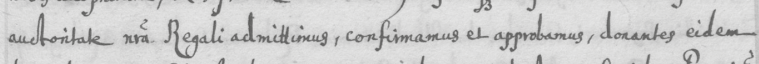

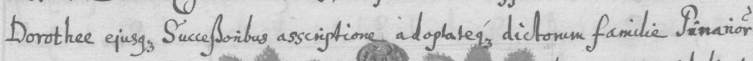

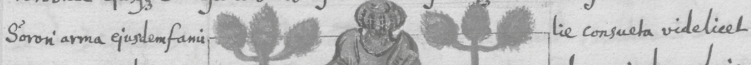
Tres Pinos vinides in una arbore e usdem colonis subguaradicas gringue. in Campo flaves ut pich ra demongtrat infia:

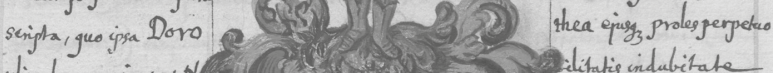

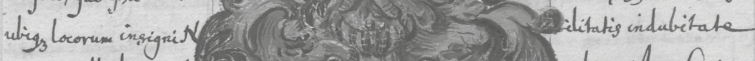

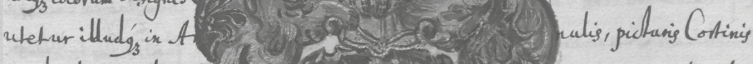

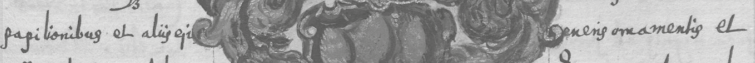
officies deferre debeal: omnibugtibertatibuset

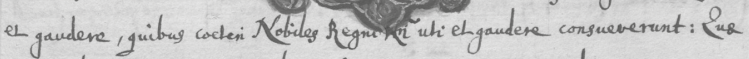

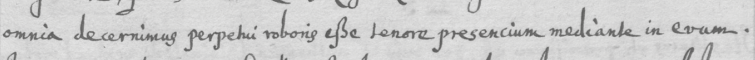

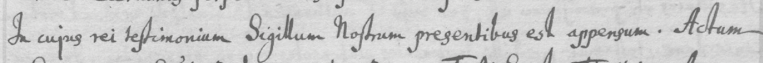
in Gonventione Gnáli Ralomiensi die Dominico Festi Sancke Trnitatig. Arno

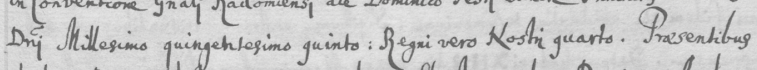
ibidem \{everendifsino el Reverendig in (hristo patiblus Dominig Andrea Archiegiscopo GreBnén et primate. Bernardino Elesto Leopoliengi, Loanke

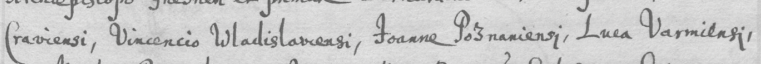

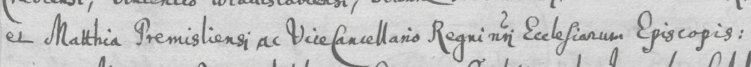
nee non Magnificis Venerabilibug en Generosig Spith kone de Lavaslaw Gastel. Lano Gracoorensi, frame de Tharnoul Sandominerse, Nicolao de LubrancB

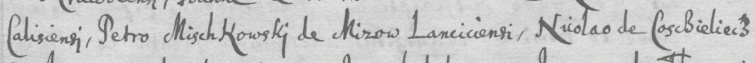
Brestens;, Kirolas de Krel Kow Funidoladiglaviensi, foanne de Tharnow 


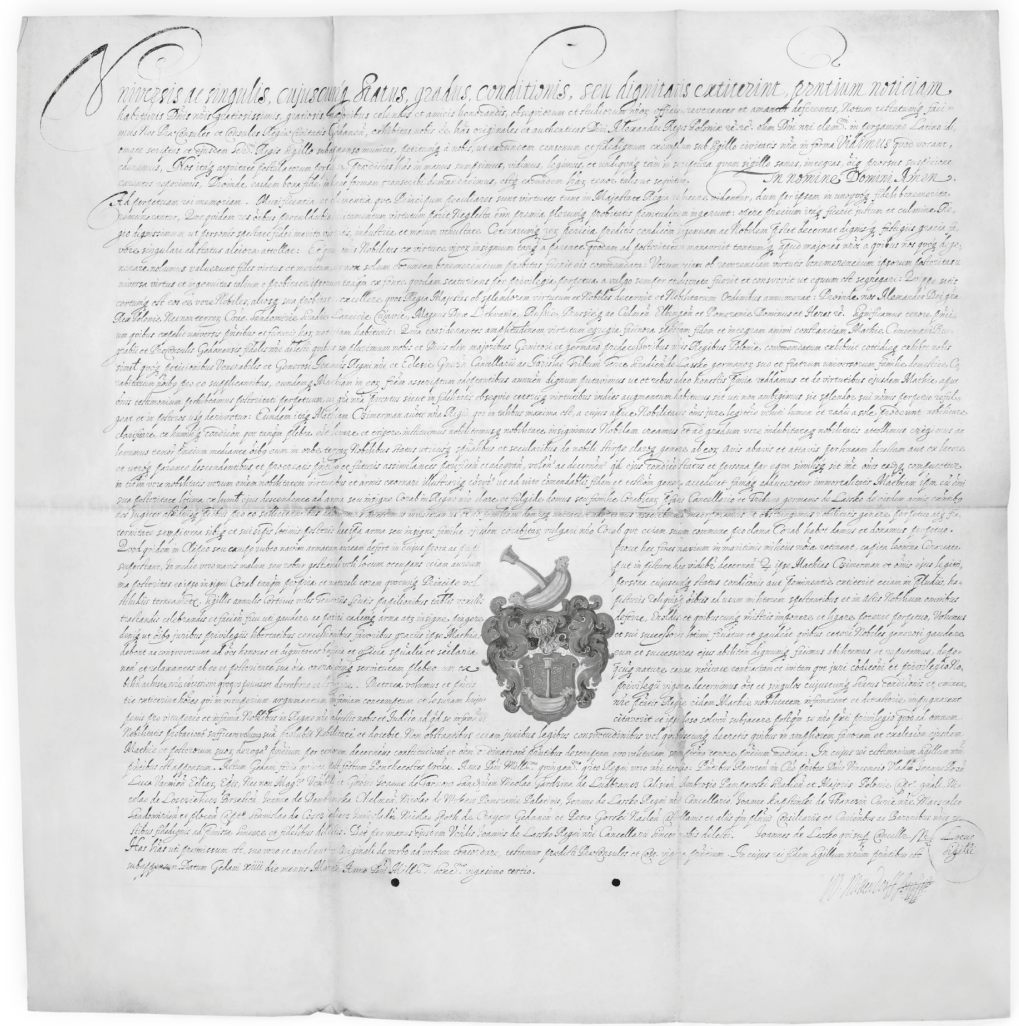

Fig. 4. Copy of Gdańsk Mayor Matthias Zimmermann's patent of nobility issued by the chancery of King Aleksander Jagiellończyk, 1623. From the collections of the State Archive in Gdańsk, 300, R/Uu, no. 18

status by being granted the right to use the Polish coat of arms of a Polish noble family or clan. Heraldic adoption had been a recognized procedure in Polish law since the time of the Polish-Lithuanian Union of Horodło (1413), when Lithuanian nobles were incorporated into the Polish nobility through adoption into Polish heraldic clans. ${ }^{38}$

38 See J. Wroniszewski, 'Adopcja horodelska w świetle praktyki adopcji herbowej w późnośredniowiecznej Polsce’ [The Horodło adoptions and the practice of heraldic adoption in late medieval Poland], in: Unia w Horodle na tle stosunków polsko-litewskich. Od Krewa do Zaręczenia wzajemnego Obojga Narodów, ed. S. Górzyński, Warszawa 2015, pp. 89-103. 


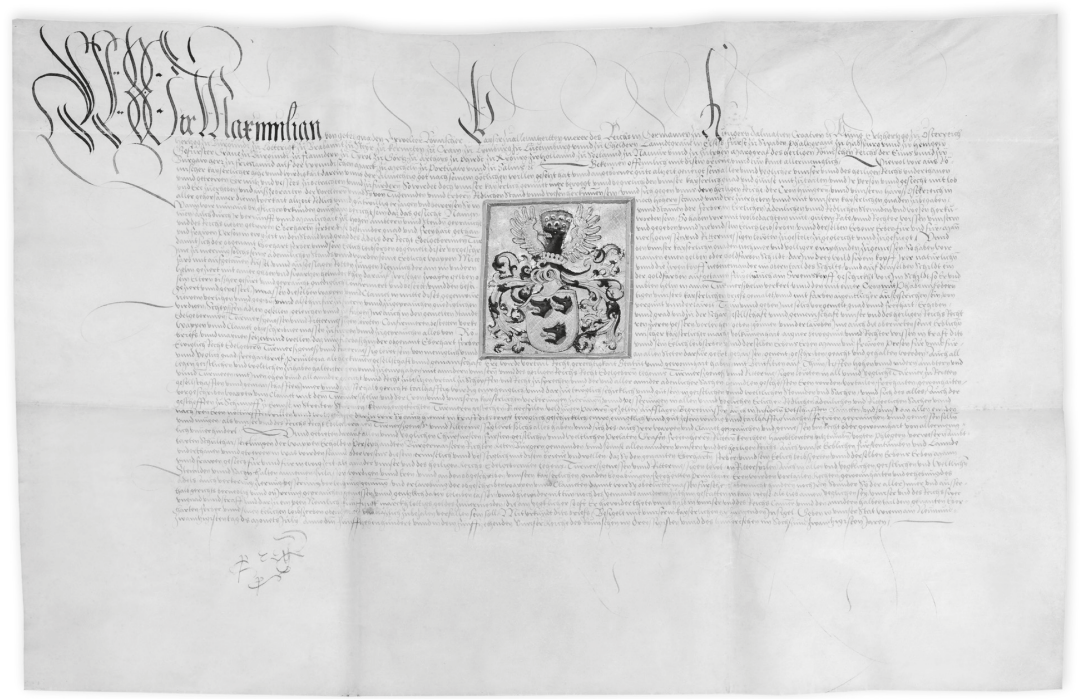

Fig. 5. Patent of nobility of Gdańsk Mayor Eberhard Ferber and his children issued by the chancery of Emperor Maximilian I, 1515. From the collections of the State Archive in Gdańsk, 300, D/82, no. 230 a.

Heraldic adoptions in the case of Gdańsk's burghers came about as a result of their dealings with Polish noble families who were among the financial elite and who held high secular and ecclesiastical office in the late medieval period, such as the Easki (Korab coat of arms) and Lubrański (Godziemba coat of arms) families. The patricians furthered their claims by making personal contacts during assemblies, diplomatic missions and visits to Gdańsk by successive kings of Poland and their noble entourages. ${ }^{39}$

The widely known and respected Szydłowiecki family adopted Gdańsk patricians under their Odrowąż coat of arms on three occasions. ${ }^{40}$ These included the earlier mentioned Gertrude Ferber as well as the wealthy merchant Johann von Werden $(1495-1554),{ }^{41}$ who

$39 \quad$ E. Bojaruniec-Król, 'Nobilitacje patrycjuszy...,' p. 30.

40 J. Michta, 'Klejnot w herbach nobilitowanych w Rzeczypospolitej w XV-XVIII wieku' [Heraldic crests of those ennobled in the Polish-Lithuanian Commonwealth during the fifteenth-eighteenth centuries], Biuletyn Polskiego Towarzystwa Heraldycznego, fasc. 12, 1994, p. 6; E. Bojaruniec, Herby mieszczan..., p. 17.

41 E. Bahr, 'von Werden, Johann,' in: AB, Bd. 2, p. 789; W. Szczuczko, 'Werden (Werda) Jan,' in: SBPN, vol. 4, ed. Z. Nowak, Gdańsk 1997, pp. 433-435; J. Zdrenka, 
was ennobled in 1525 by dint of being adopted into this heraldic clan by the brothers Krzysztof and Mikołaj Szydłowiecki. The third instance concerned Johann Fürsthe (1490-1559), ${ }^{42}$ who was adopted by Krzysztof Szydłowiecki, grand chancellor of the Crown (1467-1532), ${ }^{43}$ his brother Mikołaj (1480-1532), ${ }^{44}$ castellan of Sandomierz and treasurer of the Crown, and Stanisław of Sprowa (d. 1542/1543), castellan of Biecz. ${ }^{45}$ King Zygmunt I Stary of Poland granted these letters patent himself during his 1526 sojourn in Gdańsk. These awards of nobility required Gdańsk's patricians to undertake specific diplomatic procedures and to make financial contributions to the grand chancellor of the Crown Krzysztof Szydłowiecki, to whom they gifted substantial amounts of money, cloth and herring. ${ }^{46}$ Commercial interests and transactions with wealthy Polish noble families belonging to the financial elite were closely allied to the policies pursued by Gdańsk. Heraldic adoption, whereby patricians were granted the right to use familiar, widely used, respected coats of arms, such as that of the Godziemba clan in the case of Dorothea Zimmermann (née Ferber), adopted in 1505 by Mikołaj, voivode of Kalisz (c.1460-1524), ${ }^{47}$ and by Jan Lubrański (1456-1520), ${ }^{48}$ bishop of Poznań (Fig. 3), or

Urzędnicy..., vol. 2, pp. 368-369; D. Kaczor, 'Werden Johann von,' in: Encyklopedia gdańska..., p. 1080; S. Kościelak, 'Johann von Werden,' in: Poczet sottysów, burmistrzów..., pp. 135-138.

${ }^{42}$ F. Schwarz, 'Fürste (Forste) Johann,' in: AB, Bd. 1, p. 201; D. Weichbrodt-Tiedemann, Patrizier..., vol. 1, p. 178; J. Zdrenka, Urzędnicy..., p. 108.

43 J. Kieszkowski, Kanclerz Krzysztof Szydłowiecki. Z dziejów kultury i sztuki zygmuntowskich czasów [Chancellor Krzysztof Szydłowiecki. From the annals of art and culture during the times of King Sigismund], part 1, Poznań 1912, pp. 163-221.

44 Ibidem, pp. 32-45.

45 W. Dworzaczek, 'Odrowąż Stanisław ze Sprowy' [Stanisław Odrowąż of Sprowa], in: PSB, vol. 23, Wrocław-Warszawa-Kraków-Gdańsk 1978, pp. 555-556.

46 A. Lorkiewicz, Bunt gdański w 1525. Przyczynek do historii reformacji $w$ Polsce [The Gdańsk rebellion of 1525 and its contribution to the history of the reformation in Poland], Lwów 1881, pp. 131, 141; Z. Wojciechowski, Zygmunt Stary (1506-1548), Warszawa 1979, pp. 243-244.

47 J. Bieniak, 'Lubrański Mikołaj,' in: PSB, vol. XVIII, part 1, pp. 84-85; J. Pakulski, Krag rodzinny biskupa Jan Lubrańskiego [The family circle of bishop Jan Lubrański], Kronika Miasta Poznania, 1999, fasc. 2, pp. 32-34; idem, Ród Godziębów w średniowiecznej Polsce. Studium genealogiczne [The Godzięba clan in medieval Poland. A genealogical study], Toruń 2005, pp. 121-125.

48 A. Gąsiorowski, Lubrański Jan,' in: Wielkopolski stownik biograficzny, eds. A. Gąsiorowski, J. Topolski, Warszawa-Poznań 1981, pp. 428-429; L. Hajdukiewicz, 'Lubrański Jan,' in: PSB, vol. 18, part 1, pp. 81-84; J. Pakulski, Krag rodzinny..., pp. 28-43; idem, Ród Godziębów..., pp. 116-119. 
the Leliwa clan, into which the town councillor Hermann Bremer ${ }^{49}$ (1490-1548/1549) $)^{50}$ (Fig. 6) was adopted thanks to the efforts of Jan of Tarnów (1488-1561) ${ }^{51}$ (future grand hetman of the Crown) and his relative Jan Ciężki (1479-1527), ${ }^{52}$ castellan of Sacz and starost of Pilzno, was part of a plan designed to provide patronage for ambitious Gdańsk burghers. Naturally, these heraldic adoptions had to be approved by the king of Poland and confirmed by letters patent, as was the case when someone sought endorsement for their own coats of arms. Polish noble families readily granted Gdańsk burghers the right to use their coats of arms s probably because in doing so they gained financial and commercial advantages without the burden of legal obligations, such as inheritance rights..$^{53}$

Ennoblement paved the way for Gdańsk's burghers to pursue careers in civic office. Johann von Werden, awarded noble status in 1525 and was granted the right to use the Odroważ coat of arms, did not hold any official post in Gdańsk when he was granted his patent of nobility. However, only a year after his ennoblement, he entered public office as mayor (in 1526), and for almost a quarter of a century (until his death in 1554) he continued to shape political life in Gdańsk and Royal Prussia. ${ }^{54}$ Notably, in 1545 this patrician received another noble title, this time from the German King Ferdinand I Habsburg, later Holy Roman Emperor ${ }^{55}$, and from that time

49 AGAD, MK 42, k. 107v; Biblioteka Czartoryskich w Krakowie, Rkps. 964, k. 84; APKr, Oddział I, 1571/F.79, k. 143; MRPS, vol. 4, fasc. 1, p. 299, no. 5078; Z. Wdowiszewski, 'Regesty nobilitacji..., p. 11; Album armorum..., p. 83, no. 115; Materiaty genealogiczne..., p. 24.

50 D. Weichbrodt-Tiedemann, Patrizier..., vol. 1, p. 97; J. Zdrenka, Urzędnicy..., vol. 2 , pp. 55-56.

${ }^{51}$ W. Dworzaczek, Leliwici tarnowscy. Z dziejów możnowładztwa małopolskiego wiek XIV-XV [Leliwa family of Tarnow. From the history of the Lesser Poland magnateship in the fourteenth and fifteenth centuries], Warszawa 1971, pp. 204-207, 209-215, 217-225; idem, Hetman Jan Tarnowski. Z dziejów możnowładztwa małopolskiego [Crown Hetman Jan Tarnowski. From the history of the Lesser Poland magnateship], Warszawa 1985, passim; Ł. Winczura, Hetman Hetmanów Jan Amor Tarnowski (1488-1561) [Hetman of Hetmans Jan Amor Tarnowski (1488-1561)], Kraków 2005, passim.

52 W. Dworzaczek, Leliwici..., pp. 24, 53, 217; idem, Hetman..., pp. 336-339, 351, 357; Ł. Winczura, Hetman Hetmanów..., pp. 157, 273.

53 E. Bojaruniec, Herby mieszczan..., p. 17.

${ }_{54}$ J. Zdrenka, Gtówne..., p. 177; E. Bojaruniec, Herby mieszczan..., p. 14; E. Bojaruniec-Król, 'Nobilitacje patrycjuszy...,' p. 32.

55 Österreichisches Staatsarchiv, sygn. AdR, Werden Johann, 31 Dec. 1545, k. 1-6; K. F. von Frank, Standeserhebungen und Gnadenkte für das Deutsche Reich 

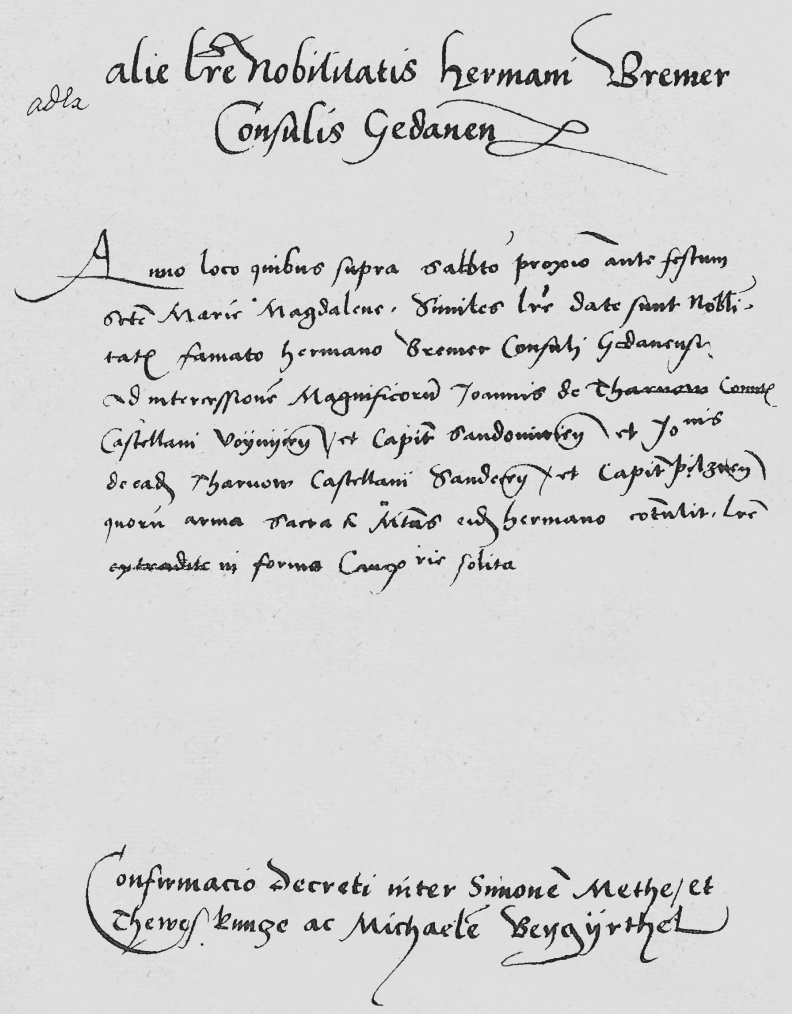

Fig. 6. Patent of nobility of Hermann Bremer recorded in Metryka Koronna, 1526. From the collections of the Central Archives of Historical Records in Warsaw, MK 42, k. 107v 
onward the Odrowąz coat of arms that he had used hitherto was always depicted on an eagle's breast (Fig. 7). This revised design of the von Werden emblem formed the heraldic prototype for later compositions seen in heraldic manuscripts and works of art such as the family tombstone, dating from 1624, located in St Mary's Church in Gdańsk. ${ }^{56}$

Members of Gdańsk's ennobled patrician families held high secular offices' in the city and successfully pursued ecclesiastical careers, serving as parish priests, episcopal officials, canons and bishops of Warmia (Ermland). A noteworthy example was Tiedemann Giese (1480-1550), ${ }^{57}$ bishop of Chełmno (Kulm) and Warmia, who was ennobled in $1519^{58}$ (Fig. 8). Family connections, which mattered greatly in appointments to particular secular offices in Gdańsk, could also be the key to securing rapid promotion for clergy within the Church hierarchy. The patrician Giese family was connected by marriage

und die Österreichischen Erblande bis 1806 sowie kaiserlich österreichische bis 1823: mit einigen Nachträgen zum "Altösterreichischen Adels-Lexikon” 1823-1913, vol. 5, Schloss Senftengg 1974, p. 204.

${ }^{56}$ K. Cieślak, Kościót cmentarzem. Sztuka nagrobna w Gdańsku (XV-XVIII w.): 'Dtugie trwanie' epitafium [The church as cemetery. Funerary art in Gdańsk (fifteentheighteenth centuries): The 'longevity' of the epitaph], Gdańsk 1992, p. 111, fig. 71.

57 F. Hipler, 'Giese Tiedemann Bartholomäus,' in: Allgemeine Deutsche Biographie, vol. 9, Lepizig 1879, pp. 151-156; F. Schwarz, 'Giese Tiedemann Bartholomäus,' in: AB, vol. 1, p. 213; A. von Giese, 'Die Danziger Patrizierfamilien Giese,' Danziger familiengeschichtliche Beiträge, 2, 1934, p. 114; W. Pociecha, 'Giese Tidemann Bartłomiej (1480-1550),' in: PSB, vol. VII, pp. 454-455; T. Borawska, 'Rodzina Giesów w Gdańsku w XV i na początku XVI wieku' [The Giese family in Gdańsk during the fifteenth and early sixteenth centuries], Acta Universitatis Nicolai Copernici'. Nauki Humanistyczno-Społeczne, fasc. 58, Historia, IX, 1973, p. 7; eadem, 'Giese Tiedemann,' in: SBPN, vol. 2, pp. 53-54; H. von Gerlinger, 'Bischof Tiedemann Giese (1480-1550) Freund des Nicolaus Kopernikus-und sein Geschlecht,' Genealogie, 15, 1981, no. 3, pp. 465-466; T. Oracki, Stownik biograficzny Warmii, Prus Ksiażęcych i Ziemi malborskiej od połowy XV do końca XVIII wieku [Biographical dictionary of Ermland, Ducal Prussia and the Marienburg Land from the mid-fifteenth to the end of the eighteenth centuries], vol. $1(A-K)$, Olsztyn 1984, pp. 64-65; S. Achremczyk, R. Marchwiński and J. Rzeracki, Poczet biskupów warmińskich [List of the bishops of Ermland], Olsztyn 1994, pp. 101-103; E. Gigilewicz, Herby biskupów warmińskich [Coats of arms of the bishops of Ermland], Lublin 2001, pp. 95-168.

58 AGAD, MK 34, k.17; PAN Biblioteka Gdańska, Ms Uph. F. 172, k.23-24; ibidem, Ms 616, k. 50-51, 85-88; MRPS, vol. IV, part 1, p. 168, no. 2908; Z. Wdowiszewski, 'Regesty nobilitacji...,' p. 10; Materiaty genealogiczne..., pp. 45-46; Album armorum..., p. 77, no. 100; B. Trelińska, 'Nobilitacje duchowieństwa w Polsce w XVI wieku' [The ennoblement of clergymen in Poland during the sixteenth century], in: Polska heraldyka kościelna. Stan i perspektywy badań, eds. K. Skupieński, ks. A. Weiss, Warszawa 2004, p. 131. 


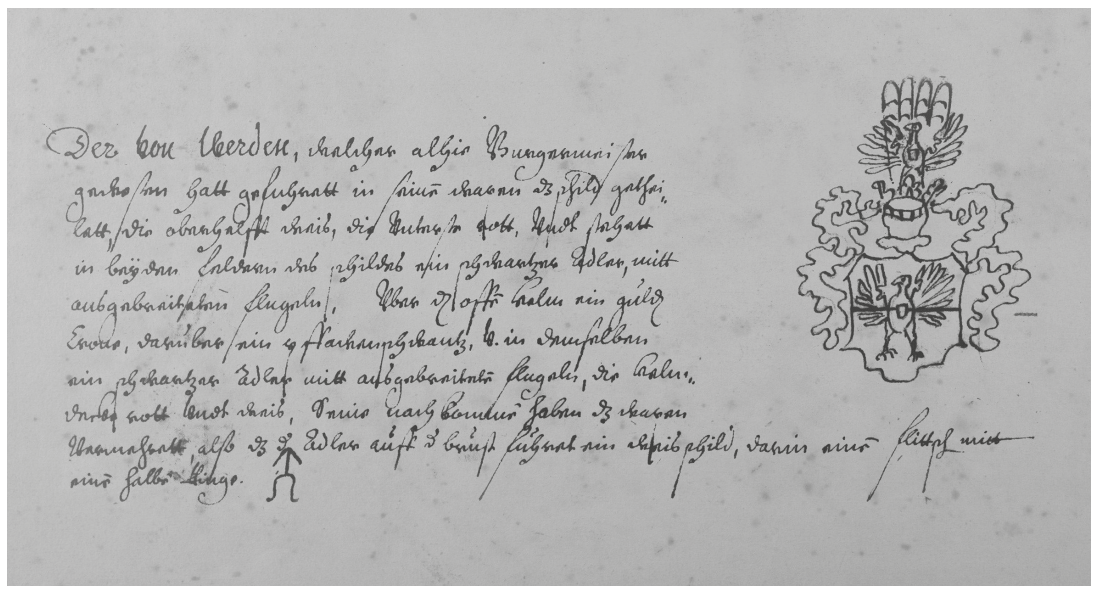

Fig. 7. Drawing and description of the coat of arms of the von Werdens a patrician family of Gdańsk, seventeenth century. From the collections of the Gdańsk Library, Polish Academy of Sciences, Ms 599, p. 20, no. 79.

to some of the most prominent families settled in Gdansk, among them the Bischoffs, the Suchtens, the Angermündes, the Feldstedtes, the Rogges and, most notably, the Ferbers, to whom Tiedemann was related through his mother Elisabeth, née Langenbecke (1455-1518). ${ }^{59}$ It was doubtless the mayor of Gdańsk Eberhard Ferber and his brother Mauritius (1471-1537), bishop of Warmia, who helped their clergyman relative on the path to ennoblement at the court of the Polish King Zygmunt I. ${ }^{60}$

Gdańsk's ennobled families constituted the city's social elite. They represented Gdańsk at assemblies of the Royal Prussian estates and at Hanseatic assemblies. They also participated in missions to the court of the subsequent kings of Poland. In building their own political and economic independence they also built the independence of Gdańsk. This city, which enjoyed burgeoning prosperity in the sixteenth and seventeenth centuries, marked by significant migration from northern and western Europe, also reached its peak as an economic powerhouse during this period.

59 Elisabeth was the daughter of Tiedemann Langenbecke and Nale (née Ferber), see PAN Biblioteka Gdańska, Ms 602, k. 61; ibidem, Ms 604, k. 62; A. von Giese, 'Die Danziger...', p. 114; T. Borawska, Rodzina Giese..., p. 140; H. von Gerlinger, 'Bischof...', p. 465 .

60 T. Borawska, Tiedeman Giese..., p. 129. 


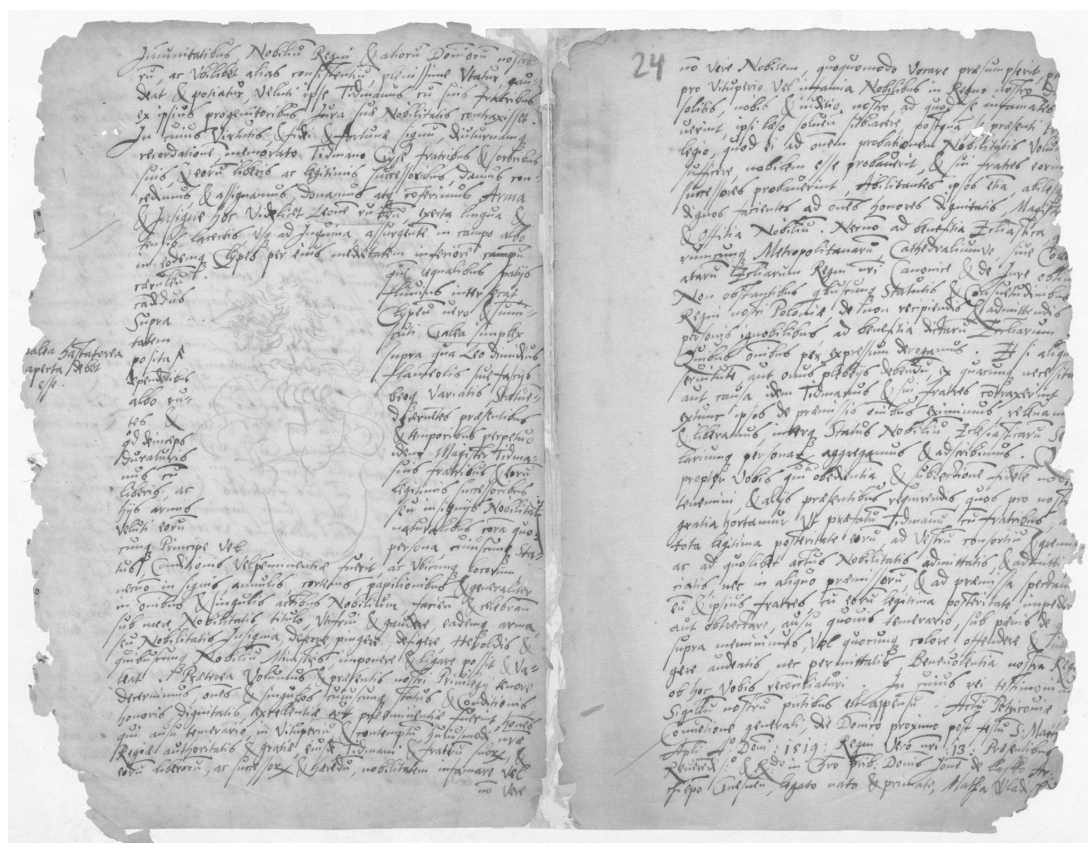

Fig. 8. Copy of Tiedemann Giese's patent of nobility issued by the chancery of King Zygmunt I Stary, sixteenth century. From the collections of the Gdańsk Library, Polish Academy of Sciences, Ms Uph f. 172, p. 24 